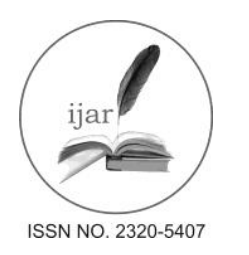

\author{
Journal homepage:http://www.journalijar.com \\ Journal DOI:10.21474/IJAR01
}

INTERNATIONAL JOURNAL

OF ADVANCED RESEARCH

RESEARCH ARTICLE

\title{
IMPROVEMENT OF NUTRITIONAL, HYGIENIC AND SENSORY PROPERTIES OF KAREISH CHEESE USING THYME AND BLACK SEEDS.
}

\author{
*Amany R. El-Bialy. \\ Food Technology Research Institute, Agricultural Research Center (ARC), Giza, Egypt.
}

\section{Manuscript Info}

Manuscript History:

Received: 12 May 2016

Final Accepted: 19 June 2016

Published Online: July 2016

Key words:

Kareish cheese, Thyme, Black

seeds, Antioxidant and

Antimicrobial activity, Sensory

evaluation.

*Corresponding Author

Amany R. El-Bialy.

\begin{abstract}
The present study was aimed to improve nutritional, hygienic and sensory properties of kareish cheese by adding Thyme (Thymus vulgaris)andBlack seeds (Nigella sativa). According such aim, Kareish cheese was manufactured using fresh buffalo skim milk and starter cultures of Lactococcus lactis subsp. lactis and Lactococcus lactis subsp. Cremoris. Thyme andblack seeds were added with different concentrations of 1,2 and $3 \%$. Total phenolic content (TPC), free radical scavenging activity (RSA), antioxidant and antimicrobial activity as well as sensory evaluation were determined in Kareish cheese in fresh and during cold storage at $4 \pm 1^{\circ} \mathrm{C}$ for 21 days. Results revealed that the kareish cheese supplemented with thyme or black seeds had high total TPC, RSA, ferric antioxidant power (FRAP). Concentration of $1 \%$ thyme or black seeds was sufficient in respect to the slowing down of mould and yeast growth, but higher concentration, i.e. $3.0 \%$ was showed more effective for inhibition of yeasts and moulds growth. This endowed potentiality can participate in keeping a good hygienic quality of kareish cheese during storage. Data showed the sample supplemented with $2 \%$ thyme or $3 \%$ back seeds had the highest flavor scores either fresh or during ripening. Data from present results concluded that thyme or black seeds can be used as an alternative natural preservative in the Kareish cheese, enhancing the nutritional value, hygienic quality and acceptable of taste.
\end{abstract}

\section{Introduction}

In developing countries, particularly in Egypt, low income people such as farmers, people in small isolated villages and native communities use Kareish cheese in their diet. Kareish cheese is one of the most popular types of soft cheese in Egypt, characterized by low fat content and an excellent dietary source of protein, calcium, phosphorous, and water-soluble vitamins (Aman, 1994; El Bagoury and Mosaad, 2002). However, it may be a vehicle for transmitting foodborne illness and causing food poisoning outbreaks due to contamination with different types of bacteria (El kholy et al., 1995).

Kareish cheese is a soft cheese commonly made and consumed in Egypt. Environmental conditions prevailing during storage, combined with the composition of the cheese often create possibilities for extensive development of mould on cheese surface, which reduces considerably its quality (Reps et al., 2002).

However, the food industry is now under pressure to reduce the use of synthetic antimicrobial chemical compounds, which appear to be experiencing a trend for 'green' consumerism and 'clean-labeling' of food products (Tajkarimi et al., 2010). As an alternative to synthetic preservatives, antimicrobial compounds from plants are becoming a positive selling point, thus creating a modern trend towards so-called 'natural' additives, preservatives and accepted by consumers (Burt, 2004). 
Thyme herb (Thymus spp.) has various functions and medical uses. It is an antimicrobial, antifungal and has an antioxidant effects. Thus regular use of this herb improves the health and longevity of individual body cells and moreover the products fortified with it. Thyme herb contains many phenolic compounds and flavonoids such as glucuronide of apigenin, luteolin, eriodyctiol, luteolin glycosids, rosmarinic acid, quercitine (Al-Amier et al., 2001; Gramza-Michalowska et al., 2008).

Black seeds (Nigella sativa L.) or its oil is used as a diuretic, lactagogue and vermifuge (Ali and Blunden, 2003). The dried seeds from black cumin are also used for sprinkling on bread or flavoring foods, especially bakery products and cheese (Takruri and Daneh, 1998). Black seeds contain 36-38\% fixed oils, proteins, alkaloids, saponins and 0.4-2.5\% essential oil (Ali and Blunden, 2003). The antioxidant, antibacterial and antifungal activities of spices and their derivatives have been investigated by some researchers (Sagdic et al., 2002; Sagdic, 2003). Many bioactive properties have been attributed to black seed, fixed oil and/or essential oil, including antibacterial ( Farrag et al., 2000), antifungal (Khan et al., 2003) and antioxidant activities (Burits and Bucar, 2000).

The present study was aimed to improve nutritional, hygienic and sensory properties of kareish cheese by adding thyme and black seed. According such aim, antioxidant and antimicrobial activity as well as sensory evaluation were determined in Kareish cheese prepared with adding different concentrations of thyme or black seeds in fresh and during cold storage at $4 \pm 1^{\circ} \mathrm{C}$ for 21 days.

\section{Materials and Methods:-}

Fresh buffalo skim milk was obtained from Animal Production Research Institute, Agricultural Research Center (ARC), Egypt. Thyme herb (Thymus vulgaris) and black

seeds (Nigella sativa) were obtained from local market. Starter cultures (Lactococcus lactis subsp. lactis and Lactococcus lactis subsp. cremoris) were obtainedfrom Chr. Hansen's Lab, Copenhagen, Denmark.

\section{Preparation of thyme and black seeds:-}

Thyme or black seeds were washed for any contaminates and crushed finely in mixer.

\section{Manufacture and treatment of Kareish cheese:-}

Kareish cheese was manufactured according to the method adopted by Fahmi (1960) and prepared in Food Technology Research Institute, as follows: skim milk (0.5\% fat and $8.75 \%$ SNF). Buffalo's skim milk was divided into seven equal portions. One batch had no herbs as a control. The second batches were fortified with thyme at the rate 1 to $3 \%$ from milk weight for treatments $T_{1}, T_{2}, T_{3}$. The latter batches were fortified with black seeds at the rate 1 to $3 \%$ from milk weight for treatments $\mathrm{T}_{4}, \mathrm{~T}_{5}, \mathrm{~T}_{6}$ and well mixed with a blender. All the treatments were heated at $85^{\circ} \mathrm{C}$ for $15 \mathrm{Sec}$. and immediately cooled to $40^{\circ} \mathrm{C}$. Sodium chloride was then added to $1 \%$ concentration with stirring until completely dissolved and all the batches were inoculated with $2 \%$ starter culture containing about $10^{8}$ $\mathrm{cfu} / \mathrm{ml}$ at the rate of the weight of skim milk at $38^{\circ} \mathrm{C}$ with stirring well. The inoculated milk batches were incubated at $35^{\circ} \mathrm{C}$ overnight until curding. The formed curd was ladled into plastic frames lined with muslin cloth, dispersed on curd and then the curd pressed by suitable weights. Resultant cheeses were stored at $4^{\circ} \mathrm{C} \pm 1^{\circ} \mathrm{C}$ for 21 days. Analysis were taken from the finished cheese every 3 days up to 21 days. All treatments were of three replicates.

\section{Determination of total phenolic content (TPC):-}

Total phenolic content in kareish cheese samples was determined according to method of Zheng and Wang (2001) by using Folin-Ciocalteu reagent and the TPC was calculated by a standard curve prepared with gallic acid and expressed as milligrams of gallic acid equivalents GAE/100gm.

\section{Determination of free radical scavenging activity (RSA) :-}

The free radical scavenging activity (RSA\%) in kareish cheese samples was measured using 2,2'-diphenyl-1picrylhydrazyl (DPPH) assay according to the method described by Brand-Williams et al. (1995). ) and expressed as percentage inhibition of the DPPH radical and was determined by the following equation:

RSA $\%=$ Abs control - Abs sample $x 100$

Abs control

Determination of Antioxidant activity :-

Antioxidant activity was measured using the ferric antioxidant power (FRAP) assay of (Benzie and Strain, 1996). 


\section{Microbiological analysis:-}

For examining the microbiological quality of kareish cheese, for each sample, $10 \mathrm{~g}$ were weighed out and transferred to a sterile blender with $90 \mathrm{ml}$ of $0.1 \%$ peptone and mixed thoroughly for $3 \mathrm{~min}$ to prepare the cheese homogenate. The number of Lactococcus spp. was enumerated using MRS agar according to method De Man et al. (1960).

Molds and yeasts were determined according to Standard Methods for Examination of Dairy Products (APHA, 1994). Coliform bacteria were enumerated according to Harrigan and McCance (1996) using Violet Red Bill Agar (VRBA). The plates were incubated at $37^{\circ} \mathrm{C}$ for $48 \mathrm{~h}$ Staphylococcus spp. and Salmonella spp. were detected according to methods recommended by (ICMSF, 1996). The count of aerobic spore forming bacteria was carried out as described by Luck (1981).

\section{Sensory evaluation:-}

Ten trained panelists from the staff members of the Dairy Research Department, Food Technology Research Institute, ARC, Egypt used a quality rating score card for evaluation of flavor (50 points) and body and texture (40 points) and appearance (10 points) (El-Shafei et al., 2008).

\section{Statistical analysis:-}

SPSS for version 17.0 (2011) computer program was used for statistical analysis. The probability $\mathrm{p}<0.05$ was considered as significant.

\section{Results and Discussion:- \\ Total phenolic content (TPC) :-}

The effect of adding different concentrations, i.e. 1-3\% of thyme powder or black seeds powder on TPC of Kareish cheese during storage periods at $5{ }^{\circ} \mathrm{C}$ for 21 days are illustrated in Table (1). As generally, supplementing of Kareish cheese with thyme or black seeds greatly increased the TPC with increasing the concentration of thyme or black seeds compared with control. As it was obvious that adding $1 \%$ thyme or black seeds highly increased the TPC by $174.41 \%, 202.79 \%$, then this rate concentration gradually increased to reach $311.16 \%, 358.13 \%$ by adding $3 \%$ thyme or black seeds respectively, at zero time of storage. The highly increase in TPC in Kareish cheese samples supplemented with black seeds was proportional to the control during storage periods. Many due to the transformation of phenolic compound which highly unstable compounds and undergo numerous enzymatic and chemical reactions during food storage (Cheynier, 2005; Poncet-Legrand et al., 2005; Es-Safi et al., 2007). During storage, the TPC gradually decreased for all treated samples, with relatively higher rate in control Kareish cheese.

\section{Free radical scavenging activity (RSA):-}

Table (2) shows the values of free radical scavenging activity(RSA) of the thyme concentrations was lower compared with those found in the black seeds supplemented with kareish cheese during storage 21 days at $4^{\circ} \mathrm{C}$. The antioxidant activity was significantly $(\mathrm{P} \geq 0.05)$ different between thyme, black seeds and control in all concentrations. The black seeds had higher antioxidant activity followed by thyme compared with control (RatzLykoet al., 2014). Along the storage period FRSA\% decreased for all Kareish cheese samples, but still the supplemented samples possessed FRSA values higher than the control cheese (Lagouri and Nisteropoulou, 2009).

\section{Ferric reducing antioxidant power (FRAP):-}

Table (3) presented that supplementing kareish cheese with thyme or black seeds proportionally increased the FRAP values of the resultant kareish cheese at zero time by increasing the additive concentration. Moreover, the significant data $(\mathrm{P} \geq 0.05)$ it was reducing the FRAP values of control and was more affected during storage rather than supplemented cheese treatment. Supplementing Kareish cheese with thyme or black seeds greatly increased FRAP values because of the high FRAP values of thyme and black seeds as reported by (Li et al., 2006 ;Șen et al., 2010).

Moulds and yeasts count in Kareish cheese during storage periods:-

The effect of adding different concentrations of thyme or black seeds on moulds and yeasts in Kareish cheese during storage periods at $4^{\circ} \mathrm{C}$ for 21 days is presented in Table (4). The moulds and yeasts count detected in the control treatment (prepared without thyme or black seeds ) cheese was $2.26 \mathrm{log} \mathrm{cfu} / \mathrm{g}$ and $4.22 \mathrm{log} \mathrm{cfu} / \mathrm{g}$ of Kareish cheese after 6 days and after 21 days of storage respectively. The cheese prepared with thyme lead to the 
inhibition and retardation of moulds and yeasts growth and lowered the maximum growth levels in the cheese. The moulds and yeasts count ranged from the beginning 1.32 to $2.21 \mathrm{log} \mathrm{cfu} / \mathrm{g}$ and 1.50 to $2.16 \mathrm{log}$ cfu $/ \mathrm{g}$ at the end of storage period in cheese samples prepared with $1 \%$ thyme or black seeds respectively, while the Kareish cheese samples prepared with 3.0\% thyme or black seeds was not detected count. From the achieved results, it is clear that the addition of thyme or black seeds at concentration of $3.0 \%$ is relatively more effective than other concentration. These results are confirmed with (Bagdassarian et al., 2013) who found that the thyme plant derivatives of essential oils are a group of inhibitors possessing antifungal activates against Aspergillus parasiticus and A.flavus. Phenolic compounds such as carvacrol, R- Cimene, A-terpinolene, Anethol, Eugenol and thymol are the most important inhibitors of fungal growth in essential oils. Thyme essential oil containing phenolic compounds such as thymol, carvacrol and cymene can be used as a natural anti- fungal substance to reduce fungal infection of pistachio. Ozcan ( 1998); De et al. ( 1999) and Khan et al. (2003) reported that the extract from Nigella sativa seeds had antifungal activity against Aspergillus parasiticus, Candida albicans and Saccharomyces cerevisiae, respectively. Many components of black seeds were characterised by Burits and Bucar (2000). Ali and Blunden (2003) using GC-MS, but the major ones were thymoquinone, p-cymene and carvacrol.

As well as Staphylococcus spp., Salmonella spp. and Sporforms were not detected in all cheese treatments either when fresh or during the storage period. Coliforms were not detected in all cheese treatments either when fresh or during the storage period. This may be due to the high hygienic condition during the preparation and the development in cheese during storage period. Lactic acid bacteria strains produce antimicrobial substances with activity against the homologous strain and microbicidal effects against gastric and intestinal pathogens and other microbes (Jacobsen et al., 1999).

Also, it was known that thymol and carvacrol, two major components of thyme, are both effective against E.coli and carvacol is more efficient (Fan and Chen, 2005). Also, the antimicrobial action of black seeds is originating from the phenolic compounds in black seeds which are considered as powerful active compounds expressing strong antimicrobial activities. From the results of the activities against pathogenic bacteria, it can be stated black seeds has general antibacterial activity against pathogenic bacteria. This endowed potentiality can participate in keeping a good hygienic a quality of cheese during storage under cold conditions (Ahn et al.,2004). Black seeds was characterized by high level of phenolics which are considered as powerful active compounds expressing strong antimicrobial activities (Luther et al., 2007).

\section{Viable cell counts of Lactococcus spp:-}

Table (4) exhibits the changes in count (log cfu/g) of Lactococcus strains (Lactococcus lactis subsp. lactis and Lactococcuslactis subsp. Cremoris) in thyme and black seeds fortified kareish cheese during refrigerated storage. In general, the viability of Lactococcus strains in thyme and black seeds supplemented kareish cheese were significantly $(\mathrm{p}<0.05)$ higher than in the control cheeses. The increase in counts during storage at 15 days could be attributed to the thyme and black seeds protease capable of degrading protein, which could have provided the essential growth factors in the form of peptides and amino acids to improve the growth of the Lactococcus strains in the cheese. These results are in accordance with those reported by Adesokan et al.(2010) and Adeniran et al.(2010).

However, the counts of Lactococcus strains in kareish cheese with $3 \%$ of thyme $(7.76 \mathrm{cfu} / \mathrm{g})$ were higher than all treatment during storage. Over storage, counts of Lactococcus strains increased until 9 days in cheese controls, while the increase in thyme and black seeds fortified cheese were more pronounced until 15 days. These results explain thyme and black seeds improved viability of the Lactococcus strains during storage of kareish cheese. Shori (2013), study the $10: 30 \%$ increase of viable cell counts (VCC) of Lactobacillus spp. and Streptococcus thermophilus, using soybean in cow-and camel-milk yogurt during refrigerated storage focuses on using additive such as soybean to improve the antioxidant and the viability of lactic acid bacteria .

\section{Sensory evaluation of the supplemented cheese during periods:-}

Sensory evaluation of Kareish cheese prepared with different concentrations of thyme or black seeds during storage periods at $5{ }^{\circ} \mathrm{C}$ for 21 days are presented in Table (5). Data showed the sample supplemented with $2 \%$ thyme or $3 \%$ back seeds had the highest flavor scores either fresh or during ripening. The flavor scores of $2 \%$ and $3 \%$ thyme or black seeds supplemented cheese after 21 days were $47,45,44$ and 47 respectively. However, continuous production of lactic acid and other organic acids lead to fragile cheese showing a gradual decrease in body and texture and appearance scores recorded for all cheese treatments up till the end of storage period. There were clear 
differences between control and cheese samples in appearance value. Similar to appearance, the cheese supplemented with $2 \%$ thyme and $3 \%$ black seeds showed flavour scores very difference to control cheese. Furthermore, the cheese supplemented with thyme and black seeds ratio showed body and texture scores very close to control cheese. Body and texture results of the control, $2 \%$ thyme and $3 \%$ black seeds-supplemented cheese after 21 days of ripening were 36, 37 and 37 respectively. In all cheese treatments, the sensory evaluation scores gradually decreased during ripening period. Also, it was clear that addition of $2 \%$ thyme or $3 \%$ black seeds produced Kareish cheese with high sensory acceptability than the control both fresh and stored in the refrigerator for 21 days. These results are in agreement with those obtained by Foda et al. (2008).

Coskun et al. (1996):-

reported that cheeses with lower concentration (1 and $2 \%$ ) herb were mostly preferred by the panelists in term of total score than higher herb concentration (4 or 5\%). On the other hand, both descriptive and hedonic evaluation presented same results.

Table 1 : The effect of adding different concentrations of thyme and black seeds on total phenolic content (TPC) of Kareish cheese during storage periods at $4 \pm 1^{\circ} \mathrm{C}$ for 21 days.

\begin{tabular}{|c|c|c|c|c|c|c|c|c|}
\hline \multirow[t]{2}{*}{ Treatment } & \multicolumn{8}{|c|}{ Storage periods at $4 \pm 1^{\circ} \mathrm{C}$} \\
\hline & Fresh & 3 days & 6 days & 9 days & 12 days & 15 days & 18 days & 21 days \\
\hline Control & $215^{\mathrm{e}}$ & $196^{\mathrm{e}}$ & $179^{\mathrm{e}}$ & $163^{\mathrm{e}}$ & $149^{\mathrm{e}}$ & $138^{\mathrm{e}}$ & $135^{\mathrm{e}}$ & $129^{\mathrm{e}}$ \\
\hline $1 \%$ thyme & $375^{d}$ & $368^{d}$ & $347^{d}$ & $339^{d}$ & $330^{\mathrm{d}}$ & $324^{\mathrm{d}}$ & $319^{d}$ & $312^{\mathrm{d}}$ \\
\hline $2 \%$ thyme & $540^{\mathrm{c}}$ & $524^{\mathrm{c}}$ & $512^{\mathrm{c}}$ & $503^{\mathrm{c}}$ & $487^{\mathrm{c}}$ & $461^{\mathrm{c}}$ & $454^{\mathrm{c}}$ & $441^{\mathrm{c}}$ \\
\hline $3 \%$ thyme & $669^{b}$ & $658^{b}$ & $645^{b}$ & $637^{b}$ & $629^{b}$ & $620^{b}$ & $612^{b}$ & $593^{b}$ \\
\hline $1 \%$ black seeds & $436^{\mathrm{a}}$ & $427^{\mathrm{a}}$ & $418^{\mathrm{a}}$ & $405^{\mathrm{a}}$ & $394^{\mathrm{b}}$ & $388^{b}$ & $379^{b}$ & $367^{\mathrm{a}}$ \\
\hline $2 \%$ black seeds & $583^{\mathrm{a}}$ & $561^{\mathrm{a}}$ & $549^{\mathrm{a}}$ & $536^{\mathrm{a}}$ & $525^{\mathrm{a}}$ & $516^{\mathrm{a}}$ & $507^{\mathrm{a}}$ & $491^{\mathrm{a}}$ \\
\hline 3\% black seeds & $770^{f}$ & $745^{f}$ & $733^{f}$ & $714^{f}$ & $696^{f}$ & $685^{f}$ & $679^{f}$ & $664^{f}$ \\
\hline
\end{tabular}

Means with different small letters in column are significant different at $(p \leq 0.05)$ to each treatment

Table 2:Free radical scavenging activity (RSA\%) of Kareish cheese supplemented with different concentrations of thyme and black seeds during storage at $4 \pm 1^{\circ} \mathrm{C}$ for 21 days.

\begin{tabular}{|c|c|c|c|c|c|c|c|c|}
\hline \multirow[t]{2}{*}{ Treatment } & \multicolumn{8}{|c|}{ Storage periods at $4 \pm 1^{\circ} \mathrm{C}$} \\
\hline & Fresh & 3 days & 6 days & 9 days & 12 days & 15 days & 18 days & 21 days \\
\hline Control & $35.71^{\mathrm{d}}$ & $32.44^{\mathrm{d}}$ & $29.18^{\mathrm{d}}$ & $28.00^{\mathrm{e}}$ & $27.10^{\mathrm{e}}$ & $25.89^{\mathrm{d}}$ & $24.11^{\mathrm{d}}$ & $22.88^{\mathrm{d}}$ \\
\hline $1 \%$ thyme & $43.60^{c}$ & $41.60^{\mathrm{c}}$ & $40.80^{c}$ & $38.90^{\mathrm{d}}$ & $37.10^{\mathrm{d}}$ & $35.00^{\mathrm{c}}$ & $33.60^{\mathrm{c}}$ & $32.50^{\mathrm{c}}$ \\
\hline $2 \%$ thyme & $48.90^{\mathrm{c}}$ & $46.50^{\mathrm{c}}$ & $44.30^{c}$ & $42.50^{\mathrm{c}}$ & $41.30^{\mathrm{c}}$ & $39.80^{c}$ & $38.90^{\mathrm{c}}$ & $37.60^{\mathrm{c}}$ \\
\hline $3 \%$ thyme & $54.50^{b}$ & $52.30^{b}$ & $50.70^{b}$ & $48.60^{c}$ & $47.00^{\mathrm{c}}$ & $44.80^{b}$ & $43.70^{\mathrm{b}}$ & $42.30^{b}$ \\
\hline $1 \%$ black seeds & $61.10^{\mathrm{a}}$ & $60.00^{\mathrm{a}}$ & $58.80^{\mathrm{b}}$ & $56.70^{\mathrm{b}}$ & $54.40^{\mathrm{b}}$ & $53.20^{\mathrm{a}}$ & $52.00^{\mathrm{a}}$ & $50.20^{\mathrm{a}}$ \\
\hline 2\% black seeds & $65.70^{\mathrm{a}}$ & $63.80^{\mathrm{a}}$ & $62.90^{\mathrm{a}}$ & $61.80^{\mathrm{a}}$ & $60.20^{\mathrm{a}}$ & $58.60^{\mathrm{a}}$ & $57.30^{\mathrm{a}}$ & $56.40^{\mathrm{a}}$ \\
\hline 3\% black seeds & $76.21^{\mathrm{e}}$ & $73.54^{\mathrm{e}}$ & $69.81^{\mathrm{e}}$ & $68,34^{\mathrm{e}}$ & $66.18^{\mathrm{e}}$ & $64.22^{\mathrm{e}}$ & $61.56^{\mathrm{e}}$ & $59.69^{\mathrm{e}}$ \\
\hline
\end{tabular}

Means with different small letters in column are significant different at $(\mathbf{p} \leq \mathbf{0 . 0 5})$ to each treatment

Table3:Ferric Reducing Antioxidant Power (mmol FeSo4/l) of Kareish cheese supplemented with different concentrations of thyme and black seeds during storage at $4 \pm 1^{\circ} \mathrm{C}$ for 21 days.

\begin{tabular}{|l|l|l|l|l|l|l|l|l|}
\hline \multirow{2}{*}{ Treatment } & \multicolumn{6}{l|}{ Storage periods at $\mathbf{4} \mathbf{1}^{\mathbf{0}} \mathbf{C}$} \\
\cline { 2 - 9 } & Fresh & $\mathbf{3}$ days & $\mathbf{6}$ days & $\mathbf{9}$ days & $\mathbf{1 2}$ days & $\mathbf{1 5}$ days & $\mathbf{1 8}$ days & $\mathbf{2 1}$ days \\
\hline Control & $27^{\mathrm{e}}$ & $25^{\mathrm{e}}$ & $22^{\mathrm{e}}$ & $19^{\mathrm{e}}$ & $18^{\mathrm{e}}$ & $16^{\mathrm{e}}$ & $15^{\mathrm{e}}$ & $13^{\mathrm{e}}$ \\
\hline $\mathbf{1 \%}$ thyme & $38^{\mathrm{d}}$ & $34^{\mathrm{d}}$ & $32^{\mathrm{d}}$ & $28^{\mathrm{d}}$ & $25^{\mathrm{e}}$ & $24^{\mathrm{e}}$ & $23^{\mathrm{e}}$ & $21^{\mathrm{d}}$ \\
\hline $\mathbf{2 \%}$ thyme & $49^{\mathrm{c}}$ & $46^{\mathrm{c}}$ & $44^{\mathrm{c}}$ & $40^{\mathrm{c}}$ & $38^{\mathrm{d}}$ & $36^{\mathrm{d}}$ & $34^{\mathrm{d}}$ & $32^{\mathrm{d}}$ \\
\hline $\mathbf{3 \%}$ thyme & $56^{\mathrm{b}}$ & $53^{\mathrm{b}}$ & $51^{\mathrm{b}}$ & $47^{\mathrm{c}}$ & $45^{\mathrm{c}}$ & $43^{\mathrm{c}}$ & $41^{\mathrm{c}}$ & $40^{\mathrm{c}}$ \\
\hline $\mathbf{1 \%}$ black seeds & $67^{\mathrm{a}}$ & $64^{\mathrm{b}}$ & $61^{\mathrm{b}}$ & $58^{\mathrm{b}}$ & $55^{\mathrm{b}}$ & $52^{\mathrm{b}}$ & $50^{\mathrm{b}}$ & $48^{\mathrm{b}}$ \\
\hline $\mathbf{2 \%}$ black seeds & $76^{\mathrm{a}}$ & $73^{\mathrm{a}}$ & $70^{\mathrm{a}}$ & $67^{\mathrm{a}}$ & $64^{\mathrm{a}}$ & $60^{\mathrm{a}}$ & $57^{\mathrm{a}}$ & $53^{\mathrm{a}}$ \\
\hline $\mathbf{3 \%}$ black seeds & $84^{\mathrm{f}}$ & $80^{\mathrm{f}}$ & $77^{\mathrm{f}}$ & $73^{\mathrm{f}}$ & $69^{\mathrm{f}}$ & $66^{\mathrm{f}}$ & $62^{\mathrm{f}}$ & $58^{\mathrm{f}}$ \\
\hline
\end{tabular}

Means with different small letters in column are significant different at $(p \leq 0.05)$ to each treatment 
Table4: The effect of adding different concentrations of thyme and black seeds on moulds and yeasts count of

Kareish cheese during storage at $4 \pm 1^{\circ} \mathrm{C}$ for 21 days.

\begin{tabular}{|c|c|c|c|c|c|c|c|c|}
\hline \multicolumn{9}{|c|}{ Mould and Yeast } \\
\hline \multirow{2}{*}{ Treatment } & \multicolumn{8}{|c|}{ Storage periods at $4 \pm 1^{\circ} \mathrm{C}$} \\
\hline & Fresh & 3 days & 6 days & 9 days & 12 days & 15 days & 18 days & 21 days \\
\hline Control & ND & ND & $2.26^{\mathrm{c}}$ & $2.92^{\mathrm{a}}$ & $3.10^{\mathrm{b}}$ & $3.32^{\mathrm{e}}$ & $3.94^{\mathrm{a}}$ & $4.22^{\mathrm{ab}}$ \\
\hline $1 \%$ thyme & ND & ND & ND & ND & $1.32^{\mathrm{a}}$ & $1.55^{\mathrm{b}}$ & $1.89^{\mathrm{b}}$ & $2.21^{\mathrm{b}}$ \\
\hline $2 \%$ thyme & ND & ND & ND & ND & ND & ND & $1.13^{\mathrm{c}}$ & $1.39^{\mathrm{c}}$ \\
\hline $3 \%$ thyme & ND & ND & ND & ND & ND & ND & ND & ND \\
\hline $1 \%$ black seeds & ND & ND & ND & ND & ND & $1.50^{\mathrm{d}}$ & $1.77^{\mathrm{d}}$ & $2.16^{\mathrm{d}}$ \\
\hline 2\% black seeds & ND & ND & ND & ND & ND & ND & ND & $1.24^{\mathrm{e}}$ \\
\hline 3\% black seeds & ND & ND & ND & ND & ND & ND & ND & ND \\
\hline Treatment & \multicolumn{8}{|c|}{ Lactic acid bacteria } \\
\hline Control & $7.33^{\mathrm{a}}$ & $7.25^{b}$ & $7.16^{\mathrm{c}}$ & $6.87^{\mathrm{d}}$ & $6.65^{\mathrm{f}}$ & $5.97^{\mathrm{e}}$ & $5.31^{g}$ & $4.88^{\mathrm{h}}$ \\
\hline $1 \%$ thyme & $7.35^{\mathrm{a}}$ & $7.57^{\mathrm{c}}$ & $7.68^{\mathrm{a}}$ & $7.84^{\mathrm{c}}$ & $7.93^{\mathrm{b}}$ & $8.12^{\mathrm{a}}$ & $7.68^{\mathrm{a}}$ & $7.12^{b}$ \\
\hline $2 \%$ thyme & $7.35^{\mathrm{a}}$ & $7.66^{d}$ & $7.75^{b}$ & $7.92^{\mathrm{a}}$ & $7.95^{\mathrm{b}}$ & $8.23^{c}$ & $7.66^{\mathrm{a}}$ & $7.23^{\mathrm{c}}$ \\
\hline $3 \%$ thyme & $7.37^{\mathrm{a}}$ & $7.81^{\mathrm{e}}$ & $8.22^{\mathrm{d}}$ & $8.56^{\mathrm{b}}$ & $8.79^{\mathrm{e}}$ & $8.84^{\mathrm{d}}$ & $8.22^{\mathrm{c}}$ & $7.76^{\mathrm{d}}$ \\
\hline 1\% black seeds & $7.31^{\mathrm{a}}$ & $7.55^{\mathrm{c}}$ & $7.71^{\mathrm{a}}$ & $7.92^{\mathrm{a}}$ & $8.11^{\mathrm{c}}$ & $8.26^{\mathrm{c}}$ & $7.74^{\mathrm{a}}$ & $7.29^{\mathrm{c}}$ \\
\hline 2\% black seeds & $7.32^{\mathrm{a}}$ & $7.61^{\mathrm{c}}$ & $7.82^{b}$ & $7.98^{\mathrm{a}}$ & $8.14^{\mathrm{c}}$ & $8.29^{c}$ & $7.78^{\mathrm{a}}$ & $7.33^{\mathrm{c}}$ \\
\hline 3\% black seeds & $7.35^{\mathrm{a}}$ & $7.77^{\mathrm{d}}$ & $7.95^{\mathrm{e}}$ & $8.23^{\mathrm{e}}$ & $8.47^{\mathrm{d}}$ & $8.66^{b}$ & $8.11^{\mathrm{c}}$ & $7.51^{\mathrm{e}}$ \\
\hline
\end{tabular}

Means with different small letters in column are significant different at $(p \leq 0.05)$ to each treatment

ND: Not detect

Table 5:Sensory evaluation of Kareish cheese prepared with different concentrations of thyme and black seeds during storage periods.

\begin{tabular}{|c|c|c|c|c|c|c|c|c|}
\hline \multirow[t]{2}{*}{ Treatment } & \multicolumn{8}{|c|}{ Storage periods at $4 \pm 1^{\circ} \mathrm{C}$} \\
\hline & Fresh & 3 days & 6 days & 9 days & 12 days & 15 days & 18 days & 21 days \\
\hline \multicolumn{9}{|c|}{ Flavor 50} \\
\hline Control & $41^{\mathrm{d}}$ & $41^{\mathrm{d}}$ & $40^{\mathrm{d}}$ & $38^{\mathrm{d}}$ & $37^{\mathrm{d}}$ & $35^{\mathrm{d}}$ & $35^{\mathrm{d}}$ & $33^{\mathrm{d}}$ \\
\hline $1 \%$ thyme & $43^{c}$ & $43^{\mathrm{c}}$ & $43^{\mathrm{c}}$ & $42^{\mathrm{c}}$ & $40^{c}$ & $40^{\mathrm{c}}$ & $39^{\mathrm{c}}$ & $39^{c}$ \\
\hline $2 \%$ thyme & $49^{b}$ & $49^{\mathrm{b}}$ & $49^{\mathrm{b}}$ & $49^{\mathrm{b}}$ & $48^{\mathrm{b}}$ & $48^{\mathrm{b}}$ & $48^{\mathrm{b}}$ & $47^{b}$ \\
\hline 3\% thyme & $47^{\mathrm{a}}$ & $47^{\text {ab }}$ & $47^{\mathrm{ab}}$ & $46^{\mathrm{ab}}$ & $46^{\mathrm{ab}}$ & $46^{\mathrm{ab}}$ & $45^{\mathrm{ab}}$ & $45^{\mathrm{ab}}$ \\
\hline 1\%black seeds & $42^{\mathrm{a}}$ & $42^{\mathrm{a}}$ & $42^{\mathrm{a}}$ & $41^{\mathrm{a}}$ & $41^{\mathrm{a}}$ & $41^{\mathrm{a}}$ & $38^{\mathrm{a}}$ & $38^{\mathrm{a}}$ \\
\hline 2\% black seeds & $46^{\mathrm{e}}$ & $46^{\mathrm{e}}$ & $46^{\mathrm{e}}$ & $45^{\mathrm{e}}$ & $45^{\mathrm{e}}$ & $45^{\mathrm{e}}$ & $44^{\mathrm{e}}$ & $44^{e}$ \\
\hline 3\% black seeds & $49^{b}$ & $49^{\mathrm{b}}$ & $49^{\mathrm{b}}$ & $49^{\mathrm{b}}$ & $48^{\mathrm{b}}$ & $48^{\mathrm{b}}$ & $47^{\mathrm{b}}$ & $47^{b}$ \\
\hline \multirow[t]{2}{*}{ Treatment } & \multicolumn{8}{|c|}{ Storage periods at $4 \pm 1^{\circ} \mathrm{C}$} \\
\hline & fresh & 3 days & 6 days & 9 days & 12 days & 15 days & 18 days & 21 days \\
\hline \multicolumn{9}{|c|}{ Body and texture 40} \\
\hline Control & $38^{\mathrm{a}}$ & $38^{\mathrm{c}}$ & $38^{\mathrm{b}}$ & $38^{\mathrm{d}}$ & $37^{\mathrm{e}}$ & $37^{\mathrm{ab}}$ & $37^{\mathrm{bc}}$ & $37^{\mathrm{t}}$ \\
\hline $1 \%$ thyme & $38^{\mathrm{a}}$ & $38^{\mathrm{c}}$ & $38^{\mathrm{b}}$ & $38^{\mathrm{d}}$ & $38^{\mathrm{e}}$ & $37^{\mathrm{ab}}$ & $36^{\mathrm{bc}}$ & $36^{\mathrm{f}}$ \\
\hline $2 \%$ thyme & $38^{\mathrm{a}}$ & $38^{\mathrm{c}}$ & $38^{\mathrm{b}}$ & $38^{\mathrm{d}}$ & $38^{\mathrm{e}}$ & $37^{\mathrm{ab}}$ & $37^{\mathrm{bc}}$ & $37^{f}$ \\
\hline 3\% thyme & $38^{\mathrm{a}}$ & $38^{\mathrm{c}}$ & $38^{\mathrm{b}}$ & $38^{\mathrm{d}}$ & $38^{\mathrm{e}}$ & $37^{\mathrm{ab}}$ & $37^{\mathrm{bc}}$ & $37^{\mathrm{t}}$ \\
\hline 1\%black seeds & $38^{\mathrm{a}}$ & $38^{\mathrm{c}}$ & $38^{\mathrm{b}}$ & $38^{\mathrm{d}}$ & $37^{\mathrm{e}}$ & $37^{\mathrm{ab}}$ & $37^{\mathrm{bc}}$ & $37^{f}$ \\
\hline 2\% black seeds & $38^{\mathrm{a}}$ & $38^{\mathrm{c}}$ & $38^{\mathrm{b}}$ & $38^{\mathrm{d}}$ & $37^{\mathrm{e}}$ & $37^{\mathrm{ab}}$ & $37^{\mathrm{bc}}$ & $37^{f}$ \\
\hline 3\%black seeds & $38^{\mathrm{a}}$ & $38^{\mathrm{c}}$ & $38^{\mathrm{b}}$ & $38^{\mathrm{d}}$ & $37^{\mathrm{e}}$ & $37^{\mathrm{ab}}$ & $37^{\mathrm{bc}}$ & $37^{f}$ \\
\hline \multicolumn{9}{|c|}{ Table 5: Continued } \\
\hline \multirow[b]{2}{*}{ Treatment } & \multicolumn{8}{|c|}{ Storage periods at $4 \pm 1^{\circ} \mathrm{C}$} \\
\hline & fresh & 3 days & 6 days & 9 days & 12 days & 15 days & 18 days & 21 days \\
\hline \multicolumn{9}{|c|}{ Appearance 10} \\
\hline Control & $9^{a}$ & $9^{\mathrm{b}}$ & $9^{\mathrm{c}}$ & $9^{\mathrm{d}}$ & $9^{f}$ & $9^{\mathrm{e}}$ & $8^{\mathrm{cd}}$ & $8^{\mathrm{ab}}$ \\
\hline $1 \%$ thyme & $9^{\mathrm{a}}$ & $9^{b}$ & $9^{\mathrm{c}}$ & $9^{\mathrm{d}}$ & $9^{\mathrm{T}}$ & $9^{\mathrm{e}}$ & $8^{\mathrm{cd}}$ & $8^{\mathrm{ab}}$ \\
\hline $2 \%$ thyme & $10^{b}$ & $10^{\mathrm{cb}}$ & $10^{\mathrm{ac}}$ & $10^{\mathrm{ad}}$ & $9^{\mathrm{t}}$ & $9^{\mathrm{e}}$ & $9^{\mathrm{a}}$ & $9^{a}$ \\
\hline 3\% thyme & $9^{\mathrm{a}}$ & $9^{\mathrm{b}}$ & $9^{\mathrm{c}}$ & $9^{\mathrm{d}}$ & $9^{f}$ & $9^{\mathrm{e}}$ & $8^{\mathrm{cd}}$ & $8^{\mathrm{ab}}$ \\
\hline
\end{tabular}




\begin{tabular}{|c|c|c|c|c|c|c|c|c|}
\hline $1 \%$ black seeds & $10^{\mathrm{b}}$ & $10^{\mathrm{cb}}$ & $10^{\mathrm{ac}}$ & $10^{\mathrm{ad}}$ & $9^{f}$ & $9^{\mathrm{e}}$ & $9^{\mathrm{d}}$ & $9^{\mathrm{a}}$ \\
\hline $2 \%$ black seeds & $10^{\mathrm{b}}$ & $10^{\mathrm{cb}}$ & $10^{\mathrm{ac}}$ & $10^{\mathrm{ad}}$ & $9^{f}$ & $9^{e}$ & $9^{\mathrm{d}}$ & $9^{\mathrm{a}}$ \\
\hline 3\% black seeds & $10^{\mathrm{b}}$ & $10^{\mathrm{cb}}$ & $10^{\mathrm{ac}}$ & $10^{\mathrm{ad}}$ & $9^{f}$ & $9^{\mathrm{e}}$ & $9^{d}$ & $9^{a}$ \\
\hline \multirow[t]{2}{*}{ Treatment } & \multicolumn{8}{|c|}{ Storage periods at $4 \pm 1^{\circ} \mathrm{C}$} \\
\hline & fresh & 3 days & 6 days & 9 days & 12 days & 15 days & 18 days & 21 days \\
\hline \multicolumn{9}{|c|}{ Total point } \\
\hline Control & $88^{\mathrm{d}}$ & $88^{\mathrm{e}}$ & $87^{\mathrm{c}}$ & $85^{\mathrm{b}}$ & $83^{\mathrm{cd}}$ & $81^{\mathrm{f}}$ & $80^{\mathrm{ab}}$ & $78^{\mathrm{ce}}$ \\
\hline $1 \%$ thyme & $90^{c}$ & $90^{\mathrm{c}}$ & $90^{\mathrm{a}}$ & $89^{c}$ & $87^{\mathrm{c}}$ & $86^{\mathrm{c}}$ & $84^{\mathrm{c}}$ & $84^{\mathrm{c}}$ \\
\hline $2 \%$ thyme & $97^{\mathrm{b}}$ & $97^{b}$ & $97^{b}$ & $97^{\mathrm{a}}$ & $95^{\mathrm{b}}$ & $94^{\mathrm{b}}$ & $94^{\mathrm{b}}$ & $93^{b}$ \\
\hline $3 \%$ thyme & $94^{\mathrm{e}}$ & $94^{\mathrm{ab}}$ & $93^{\mathrm{e}}$ & $93^{\mathrm{e}}$ & $93^{\mathrm{a}}$ & $92^{\mathrm{a}}$ & $90^{\mathrm{a}}$ & $90^{\mathrm{a}}$ \\
\hline $1 \%$ black seeds & $90^{c}$ & $90^{\mathrm{c}}$ & $90^{\mathrm{a}}$ & $89^{c}$ & $91^{\mathrm{ab}}$ & $87^{\mathrm{d}}$ & $84^{\mathrm{c}}$ & $84^{\mathrm{c}}$ \\
\hline $2 \%$ black seeds & $94^{\mathrm{e}}$ & $94^{\mathrm{ab}}$ & $94^{\mathrm{e}}$ & $93^{\mathrm{e}}$ & $91^{\mathrm{ab}}$ & $91^{\mathrm{e}}$ & $90^{\mathrm{a}}$ & $90^{\mathrm{a}}$ \\
\hline 3\%black seeds & $97^{b}$ & $97^{b}$ & $97^{b}$ & $97^{\mathrm{a}}$ & $94^{\mathrm{e}}$ & $94^{b}$ & $93^{e}$ & $93^{b}$ \\
\hline
\end{tabular}

Means with different small letters in column are significant different at $(\mathbf{p} \leq \mathbf{0 . 0 5})$ to each treatment.

\section{Conclusion:-}

The results obtained in this study indicate that Kareish cheese supplemented with thyme or black seeds had high total phenolic content (TPC) and antioxidant activity and inhibits the mould and yeast growth. Concentration of $1 \%$ thyme or black seeds was sufficient in respect to the slowing down of mould and yeast growth, but higher concentration, i.e. $3.0 \%$ was showed more effective for inhibition of yeasts and moulds growth. This endowed potentiality can participate in keeping a good hygienic quality of kareish cheese during storage. The concluded that thyme or black seeds can be used as an alternative natural preservative in the Kareish cheese, enhancing the nutritional value, hygienic quality and acceptable of taste.

\section{References:-}

1. Ahn, J., Grun, I.U. and Mustapha, A. (2004): Antimicrobial and antioxidant activities of natural extracts in vitro and in ground beef. Journal of Food Protection, 67: 148-155.

2. Adeniran, A.H., Abiose, S.H. and Ukeyima, M.T. (2010): Microbiological assessment of propioticated ginger-based beverages. J. Nutr. Food Sci., 40:209-220.

3. Adesokan, I.A., Abiola, O.P. and Ogundiya, M.O. (2010): Influence of ginger on sensory properties and shelf-life of Ogi, a Nigerian traditional fermented food. African J. Biotech., 9: 1803-1808.

4. Al-Amier, H., Mansour, B.M, Toaima, N., Craker, L. and Shetty, K. (2001): Tissue culture selection for phenolics and rosmarinic acid in thyme. J. Herbs, Spices Med. Plants, 8(1): 31-42.

5. Ali, B.H. and Blunden,G. (2003): Pharmacological and toxicological properties of Nigella sativa. Phytopherapy Research, 17:299-305.

6. Aman, I. M. (1994): Microbiological quality of Kareish cheese in Kafr ElSheikh City. Assiut. Vet. Med. J., 31:182-189.

7. American Public Health Association (APHA), (1994): Compendium of Methods for the Microbiological Examination of Foods Fourth edition. F.P. Downes and K. Ito (editors), American Public Health Association, Washington, D.C. 4thedition.

8. Bagdassarian, V.L., Bagdassarian, K.S. and Stefanova, M. (2013): Phenolic profile, antioxidant and antimicrobial activities from the Apiaceae family (dry seeds). Mintage Journal of Pharmaceutical and Medical Sciences, 2: 26-31.

9. Benzie, I.F. and Strain, J.J. (1996): The ferric reducing ability of plasma (FRAP) as a measure of antioxidant power: The FRAP assay. Anal. Biochem., 239: 70-76.

10. Brand-Williams, W., Cuvelier, M.E and Berset, C. (1995): Use of free radical method to evaluate antioxidant activity. Lebensmittel-Wissens- chaft and Technology, 28: 25-30.

11. Burits, M. and Bucar, F. (2000): Antioxidant activity of Nigella sativa essential oil. Phytotherapy Research $14,323-328$.

12. Burt, S. (2004): Essential oils: Their antibacterial properties and potential applications in foods - A review, Int. J. Food Microbiol., 94: 223-253.

13. Cheynier, V. (2005): Polyphenols in foods are more complex than often thought. Amer. J. of Clin. Nutr., 81: 223S-229S. 
14. Coskun, H., Bakici, I. and Isik, S. (1996): A study on the determination of herb addition rate in van herby cheese. Yuzuncu Yil Universitesi, Ziraat Fakultesi Dergisi, 6: 97-103.

15. De, M; De, AK. and Banerjee, AB. (1999): Antimicrobial screening of some Indian Spices. Phytotherapy Research, 13: 616-618.

16. De Man, J.C., Rogosa, M. and Sharp, E. M. (1960): A medium for the cultivation of lactobacilli. J Appl. Bacteriol., 22: 130-134.

17. El Bagoury, A. N. and Mosaad A. A. (2002): Incidence of Salmonella and Escherichia coli in Kareish cheese with special reference to heat stable enterotoxin producing Escherichia coli using polymerase chain reaction. Minufia Vet. J., 2:59-66.

18. El-Kholy, A. M., Hafez R.S. and Mahmoud M.D. (1995): Occurrence of some food poisoning bacteria in Egyptian soft cheese. BeniSuef Vet. Med. Res ,7:342-351.

19. El-Shafei, Kawther, Dabiza, M. A, Sharaf, O.M. and Effat, B.A. (2008): A mixed culture of Propionbacterium thoenia, Lactobacillus rammasus and lactobacillus palntrum as protective culture in kareish cheese Pol. J Food Nutrition Sci., 5(8):433-441.

20. Es-Safi, N, Ghidouche, S. and Ducrot, P.H. (2007): Flavonoids. Hemisynthesis, reactivity, characterization and free radical scavenging activity. Molecules, 12: 2228-2258.

21. Fahmi, A.H. (1960): Kariesh cheese. Journal Agriculture Science, Vol. 3, 1

22. Fan, M. and Chen, J. (2005): Studies on antimicrobial activity of extracts from thyme. Wei Sheng Wu Xue Bao., 41:499-504.

23. Farrag, H.A., El-Bazza, Z.E., El-Fouly, M.E. and El-Tablawy, S.Y. (2000): Effect of gamma radiation on the bacterial flora of Nigella sativa seeds and its oil constituents. Act Pharma, 50:195-207.

24. Foda, Mervat; Faten, L., Seleet and El-Ghorab, A.H. (2008): Sensory Evaluation and Related Volatile Components of White Herby Cheese. International Journal of Dairy Science, 3: 160-169.

25. Gramza-Michalowska, A., Hes, M. and Tea, J.K. (2008): Tea extracts antioxidative potential in emulsified lipid systems. Acta Sci. Pol. Technol. Aliment., 7: 29-34.

26. Harrigan, W.F. and McCance, M.E. (1996): Laboratory Method in Microbiology. Academic press, London and New York, 292-293.

27. ICMSF, International Commission on Microbiological Specification for Food, (1996): Micro-organisms in Food Microbiological Specification of Food Pathogens. Back Academic and Professional. T.A. Roberts, A.C. Baird- Parker and R.B. (eds).

28. Jacobsen, C. N., Rosenfeldt, N. V., Hayford, A. E., Møller, P. L., Michaelsen, K. F., Paerregaard, A. and Jakobsen, M. (1999): Screening of probiotic activities of forty seven strains of Lactobacillus spp. By in vitro techniques and evaluation of the colonization ability of five selected strains in humans. Applied and Environmental Microbiology, 65:4949-4956.

29. Khan, M.A., Ashfaq, M.K., Zuberi, H.S., Ahmood, M.S. and Gilani, A.H. (2003): The in vivo antifungal activity of the aqueous extract from Nigella sativa seeds. Phytotherapy Research, 17:183-186.

30. Lagouri, V. and Nisteropoulou, E. (2009): Antioxidant properties of O. onites, T. vulgaris and O. basilicum species grown in Greece and their total phenol and rosmarinic acid content. J. Food Lipids, 16: 484-498.

31. Li, Y., Guo, C., Yong, J., Wei, J., Xu, J. and Chang, S. (2006): Evaluation of antioxidant properties of pomegranate peel extract in comparison with pomegranate pulp extract. Food Chem., 96: 254-260.

32. Luck, H. (1981): Quality control in the dairy industry .In :R.K. Robinson (Ed.). Dairy Microbiology Vol.11.pp.313-315.Applied Sci. Publishers, Ltd., England.

33. Luther, M., Parry,J., Moore, J., Meng, J., Zhang, Y. and Cheng, Z. Yu. (2007): Inhibitory effect of Chardonnay and black raspberry seed extracts on lipid oxidation in fish oil and their radical scavenging and antimicrobial properties. Food Chemistry 104, 1065-1073.

34. Ozcan, M. (1998): Note: Inhibitory effects of spice extracts on the growth of Aspergillus parasiticus NRRL2999 strain. Zeitschrift fur Lebensmittel Untersuchung Forschung A ,207: 253-255.

35. Poncet-Legrand, C., Edelmann, A., Putaux, J.L., Cartalade, D., Sarni-Manchado, P. and Vernhet, A. (2005): Poly (Lproline) interactions with flavan-3-ols units: Influence of the molecular structure and the polyphenol/protein ratio. Food Hydrocolloids, 20: 687-687.

36. Ratz-Lyko, A., Herman, A., Arct, J. and Pytkowska, K. (2014): Evaluation of antioxidant and antimicrobialactivities of Oenothera biennis, Borago officinalis, and Nigella sativa seedcake extracts. Food Sci. Biotechnol. 23, 1029-1036.

37. Reps, A., Drychowski, L.J., Tomasik, J. and Niewska, K.W. (2002): Natamycin in ripening cheeses. Pakistan Journal of Nutrition, 1(5):243-247. 
38. Sagdic, O. (2003). Sensitivity of four pathogenic bacteria to Turkish thyme and oregano hydrosols. Food Sci. Technol. - LWT, 36:467-473.

39. Sagdic, O., Kuscu, A., Ozcan, M., Ozcelik, S. (2002): Effects of Turkish spice extracts at various concentrations on the growth of Escherichia coli O157:H7. Food Microbiol.19, 473-480.

40. Șen, N.; Kar, Y. and Tekeli, I . (2010): Antioxidant activities of black cumin (Nigella sativa L.) seeds cultivating in different regions of Turkey. J. Food Biochem., 34: 105-119.

41. Shori, A.B. (2013): Antioxidant activity and viability of lactic acid bacteria in soybean-yogurt made from cow and camel milk. Journal of Taibah University for Science 7 : 202-208.

42. SPSS (2011): SPSS for Windows. Release 10 (October 2011) Standard Version.

43. Tajkarimi, M.M., Ibrahim, S.A. and Cliver, D.O.(2010): Antimicrobial herb and spice compounds in food, Food Control, 21:1199-1218.

44. Takruri, H.R. and Dameh, M.A. (1998): Study of the nutritional value of black cumin seeds (Nigella sativa L.). J. Sci. Food Agric. 76, 404-410.

45. Zheng, W. and Wang, S.Y. (2001): Antioxidant activity and phenolic compounds in selected herbs. Journal of Agricultural and Food chemistry, 49: 5165-5170. 